\title{
Researches on Anti-reflection Coating (ARC) Methods Used in PV Systems
}

\author{
N. Ekren
}

\begin{abstract}
With the development of PV systems' technology over the years and the reduction of production costs, PV systems are now being used for electricity generation. PV systems are listed among the renewable energy sources as the only requirement is solar energy and electricity generation is carried out without any fuel and waste. Solar cells used in PV systems are adversely affected by extremes of temperature, shading, reflection, and pollution. It is known that before sunrays reach the cell's surface, some of them disappears from the protective glass surface and are reflected back from the cell through the glass surface. Antireflection coatings (ARC) are used to reduce the energy loss and increase solar cell efficiency and output power. $\mathrm{SiO}_{2}$ and $\mathrm{MgF}_{2}$ are the most commonly used solutions among these coatings. It has been seen that the most efficient applications, with anti-reflection coatings as single, double, triple and more layers, are in triple layers applications. It has been observed that applications to the protective glass surface have self-cleaning properties, and $\mathrm{TiO}_{2}$ and $\mathrm{ZrO}_{2}$ are frequently used for this. The reflectance index of the protective glass, which is normally 1.51 , can be reduced to 1.20 in silicone cells and 1.28 in thin film surfaces with the AR coatings.
\end{abstract}

Index Terms-PV systems, Anti-reflection, Anti-reflective Coating, Reflection index.

\section{INTRODUCTION}

$\mathrm{I}^{\mathrm{N}}$ N RECENT YEARS, the share of fossil-fuelled energy sources in electricity generation has been reduced, so renewable energy sources now have more share. When fossilfuelled resources are used for electricity generation, they release hazardous wastes to the environment. Recently, some studies have been carried out on the environmental pollution caused by these wastes, whose effects lead directly or indirectly to major problems [1]. The use of renewable energy does not generate any waste, so this is a key advantage for nature and human health. Including solar, wind, hydro and biofuel as sources, the use of renewable energy sources as an alternative to fossil fuel usage has gained momentum worldwide. One of the most important renewable energy sources is solar energy. The most common method is the production of electricity by photovoltaic panels, although methods such as solar chimney, condensed solar energy used in electricity generation from solar energy are used. Until 2030, the electricity demand in the world is predicted to increase by $76 \%$.

N. EKREN, is with Department of Electrical and Electronics Eng., Marmara University, Istanbul, Turkey, (e-mail: nazmiekren@marmara.edu.tr) iD

Manuscript received September 18, 2017; accepted January 9, 2018. DOI: $10.17694 /$ bajece.402004
The energy of $5100 \mathrm{~J}$ per hour that reaches the earth from the sun is the amount of energy consumed by all people in a year. It is known that in photovoltaic systems, $30 \%$ of the solar energy is reflected back from the panel surface, and about $70 \%$ of the solar energy reaches the solar cell [2]. In this context, solar energy is benefited by the conversion of the energy it contains with the photovoltaic systems to electricity.

Looking at the types of solar panels used in photovoltaic systems, monocrystalline ( $\mathrm{SC}-\mathrm{Si}$ ) and polycrystalline (MC-Si) panels appear to be at the forefront. In 2014, 92\% of total production was achieved with monocrystalline and polycrystalline panels [3]. The percentage of thin film surfaces (CdTe, $\mathrm{CuSe}_{2}$ (CIGS)) is less than that of silicon-based surfaces [4]. On the other hand, the production cost of thin films is lower than that of Silicon cells, and thus the production of thin films has accelerated in recent years [5]. The production cost in the silicon panels was 8.5 USD / w in 1995 and 1.1 USD / w in 2015 [6]. Despite the decrease in production costs, the photovoltaic systems which are more expensive and have newer technologies than other electricity generation methods have a share of $1.5 \%$ in world electricity generation in 2016. The share of fossil-fuelled resources is $75.5 \%$, which indicates that PV systems are very backward in the same year [7].

\section{PV TECHNOLOGY}

The applications to utilize solar energy, both in heating and in electricity generation, have been date back to 1960s. The structure of a solar panel consists of a solar cell and protective outer glass. Solar cells vary in their physical and chemical form with the yield, based on the nature of the material, such as silicon ( $\mathrm{Si}$ ) or gallium-arsenide (GaAs). An air gap is the necessity of the distance between the solar cell and the protective glass to zero. The sun's rays entering the air gap will scatter and break, as well as they will cause oxidations in the connections of the cells. For these reasons, there should be no air gap. The protective exterior glass structure is made to be straight and as thin as possible, but it is manufactured resistant to physical factors. In addition to making the protective glass straight, there are also solar panels manufactured by the Fresnel eye method [8].

The efficiency of solar panels is decreased by the effect of temperature increase or overheating, due to solar radiation scattered or reflected by the dirt on the surface, and atmospheric phenomena such as low solar radiation and cloudiness [9]. The real danger for solar panels is reduced efficiency due to overheating. Therefore, cooling technologies are being developed. Up to $20 \%$ efficiency increase was observed in the oil cooling operation [10]. 


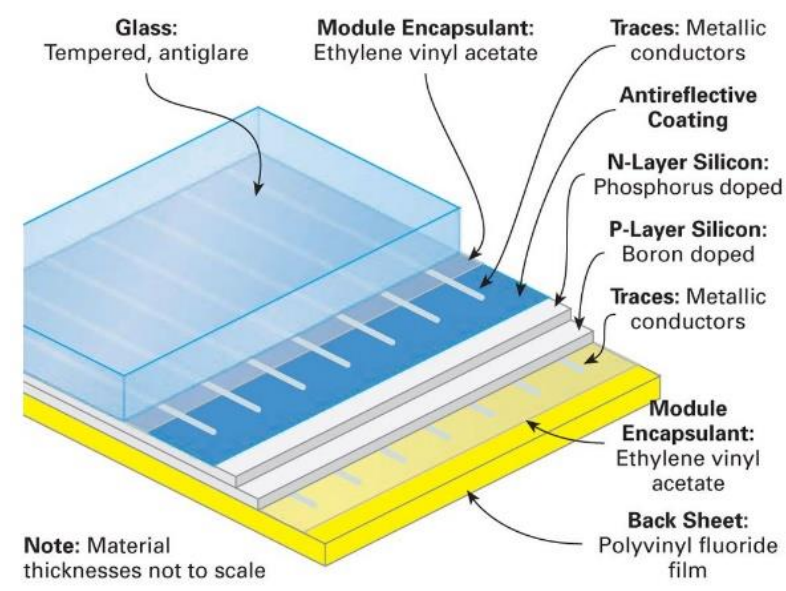

Fig.1. Layers of Solar Cell

physical properties of the coatings are expected to remain unchanged and must be resistant to corrosion and oxidation [2]. Another common feature of anti-reflective coatings is that they can remain stable over long periods of temperature changes and various seasonal weather conditions. Another expectation with this seasonal change is that the surface is well adhered. The resistance against seasonal conditions is on the foreground in the coatings made on the glass surface.

The protective glass reflectance index used for solar panels is 1.51, the silicon cells are 4.71 and the air is 1.0 [13]. Antireflection coatings are expected to bring the reflectance index on the glass surface to zero. Because of the mechanical properties of the thin film surfaces, the solar panels used for the silicon cells achieved more efficient results [14]. In studies to reduce the reflectance index, it has been found that $\mathrm{SiO}_{2}$ is coated with a lower index as a substrate and a different mixture. Implementing double layer coating (DLARC) on the coatings on the cell gave better mechanical and electrical results than single layer coating (SLARC). However, multi-layered coatings (MLARC) made from thinner layers than single- and double-layer coatings also showed favourable results from single- and double-layer coatings. application methods.

To investigate anti-reflection coatings, it is first necessary to classify solar panels according to cell types. Solar cells are made of Silicon Crystal based or Thin Film technology.

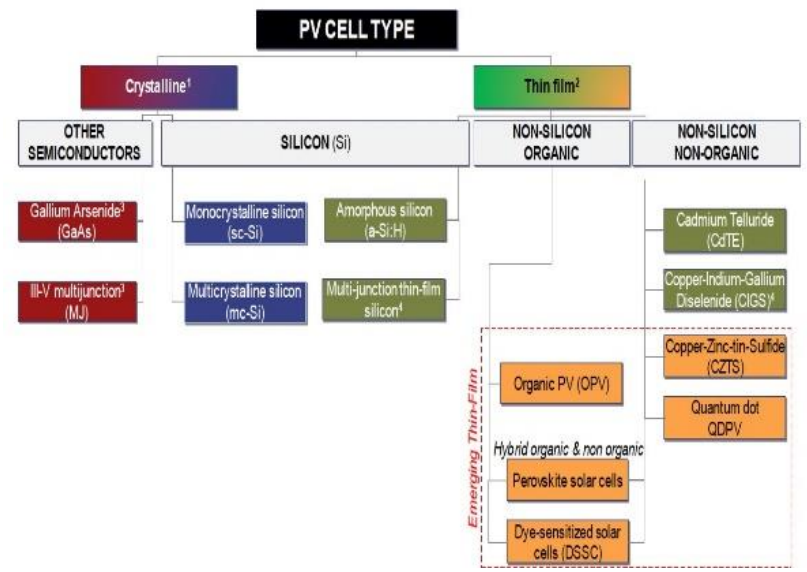

Fig.2. Classifying of PV Cells [11]

\section{RESEARCH AND METHOD}

Considering the studies of increasing the efficiency of solar panels, coating methods are applied according to cell types. Anti-reflection (AR) is defined as preventing reflection or refraction of sunlight coming to the cell surface. Anti-reflection applications technics are;

- Physical vapour deposition

- Chemical vapour deposition

- Thermal spraying

- Electro deposition

- Electro-less deposition

- Diffusion coating

- $\quad$ Laser based [12].

When the general properties used in these methods are examined, it is seen that the permeability of the coatings is less than $2.5 \mu \mathrm{m}$. In seasonal conditions, such as rain or snow, the

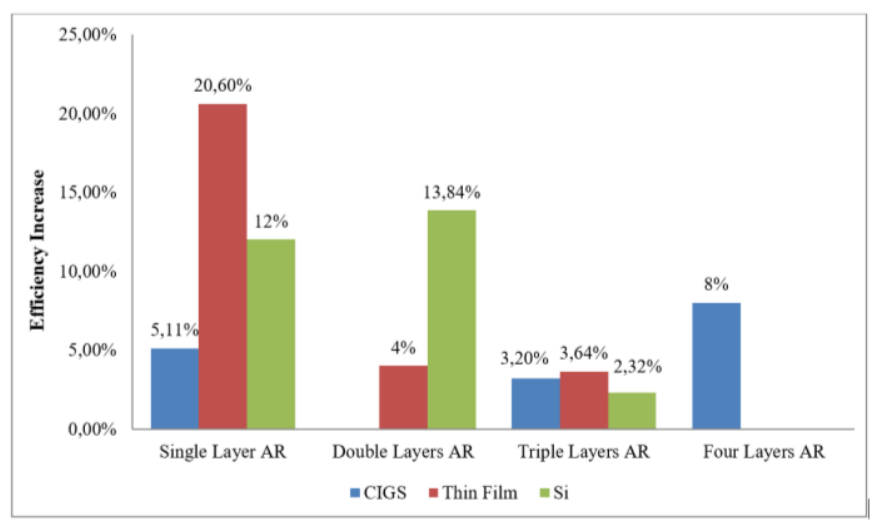

Fig.3. Effect of Anti-reflection Coating to Efficiency

When the literature studies are investigated, the anti-reflection coating works are concentrated on single, double and triple layer coatings. In case of working with four or more floors, the light transmittance decreased due to the increase of coating thickness, which led to decrease in efficiency and open circuit voltage. Silicon cells used as working surfaces have been studied with other thin film cell types, especially CIGS Thin film solar cells.

In the column of single-layer studies, an efficiency increase of $5.11 \%$ was obtained in CIGS cells. GIGS cell efficiency which is normally $\% 16.7$ increased to $17.6 \%$ with a single layer coating. $\mathrm{MgF}_{2}$ was used at a thickness of about $120 \mathrm{~nm}$ [15]. In the case of investigating other thin film types, the efficiency was increased from $1.31 \%$ to $1.65 \%$ after coating and a total increase of $20.60 \%$ was obtained. $\mathrm{ZnO}$ cell coating of $80 \mathrm{~nm}$ thickness was performed [16]. A single layer of $\mathrm{Ag}+\mathrm{SiO}_{2}$ coating was applied to the silicon cells and a $12 \%$ efficiency gain was achieved by supporting this coating with a lens for light condensation [17].

In the two-layer anti-reflection applications; $\mathrm{SiO}_{2}$ and nano $\mathrm{TiO}_{2}$ applied to the silicon cell surface and was obtained 400 $\mathrm{nm}$ thickness coating. With these coatings, a maximum 
efficiency increase of $16 \%$ was achieved while an average increase of $13.84 \%$ was achieved [18]. In another study on thinfilm cells, the $\mathrm{SiO}_{2}$ mixture was applied and the efficiency of the thin-film surface, which is $9.83 \%$, was increased to $10.24 \%$. The thickness of this two-layer application was around $90 \mathrm{~nm}$ [19].

$\mathrm{Si}-\mathrm{HC}$ is coated on CIGS thin-film cell as a triple-layers antireflective coating. A thickness of $120 \mathrm{~nm}$ was obtained and an efficiency increase of 3.2\% was obtained [20]. With $\mathrm{SiO}_{2}$ coating on $\mathrm{ZnO}$ thin film, the thickness was $300 \mathrm{~nm}$, and the triple layers coating efficiency increased by $3.64 \%$ [21]. In the triple-layers coating applied on the silicon cell surface, the protective glass was removed and $\mathrm{TiAl}_{2}$ mixture solvent was used. This solvent was applied to the cell surface in triple layers and after each layer was dried the next layers were applied. With this mixture, $2.32 \%$ efficiency increase was obtained in silicon cells. The open circuit voltage was increased from 9.49 volts to 10.31 after coating [2].

The CIGS surface was used in four-layer coatings. This is why $\mathrm{MgF}_{2}$ used does not decrease the required reflectivity when a single-layer coating is applied and does not increase the efficiency. For this reason, $\mathrm{HfO}_{2}, \mathrm{TiO}_{2}$ and $\mathrm{ZrO}_{2}$ were used in the bottom and 2 nd and 3 rd layers respectively, and $2 \mu \mathrm{m} \mathrm{MgF} 2$ was used as the anti-reflection layer in the outermost layer. Optical losses decreased from $9 \%$ to $4 \%$, while CIGS cell efficiency increased by $8 \%$ [22].

In addition to these coatings, a mold was placed on the protective glass surface to serve as a lens, after which $\mathrm{SiO}_{2}$ was applied on the mold, and an efficiency increase of $7.88 \%$ was achieved with this combination [23].

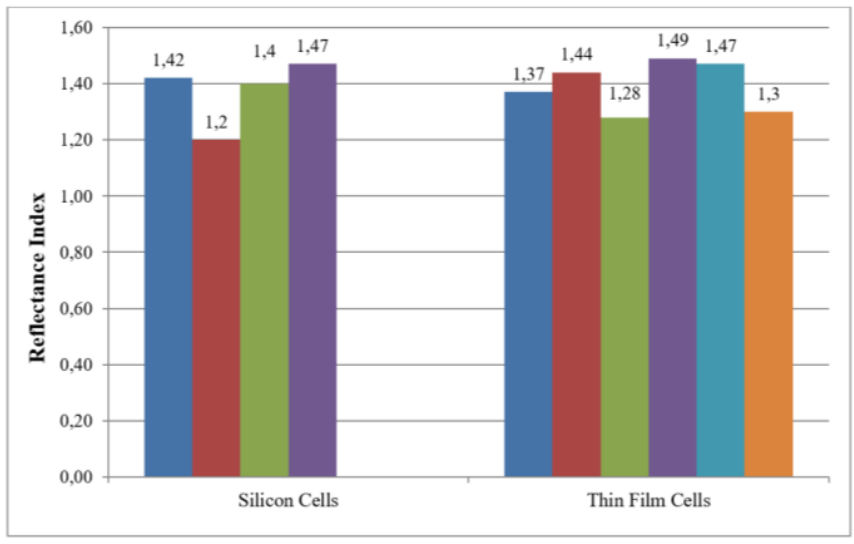

Fig.4. Effect of Anti-reflection Coating to Reflectance Index

It is aimed to pass the sunrays from the surface to the solar cell without any loss by the anti-reflection coatings. These studies are applied on the cell surface, protective glass surface and both cell surface and protective glass. In anti-reflection workings, it is usually seen to be applied to the protective glass surface and between the cell and the glass surface.

Coatings applied on silicone cells were investigated; a triplelayer $\mathrm{SiO}_{2}$ coating was applied on a polycrystalline solar cell with an index gain of $5.9 \%$ and reduced to 1.42 . In a study on a monocrystalline surface, a reflectance index of 1.19-1.21 was obtained [24]. In the study on radiation-hardened highefficiency silicon cells (RHHES), single-layer tested with the $\mathrm{SiO}_{2}$ mixture resulted in 1.46 , and 1.4 reflectance index when triple-layers were applied [25]. In another study, the application of nano- $\mathrm{ZnO}$ on the protective glass of silicon cells was modelled. The thickness of the nano- $\mathrm{ZnO}$ coating modelled by the finite element method is considered to be $400 \mathrm{~nm}$. The loss of $4 \%$ within this coating between the air and glass was estimated to be reduced to $1.5 \%$ and the reflection index to be 1.47 [26].
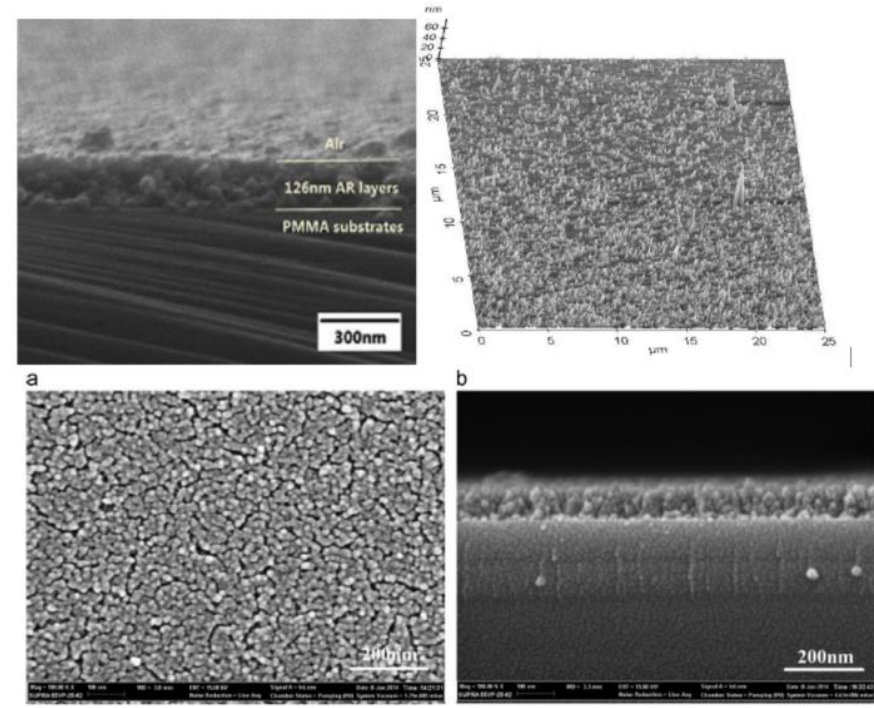

Figure 5. Electron microscopy images of anti-reflection coating studies [12, 1927$]$

When working on the thin film; a self-cleaning feature was applied to the protective glass. $\mathrm{TiO}_{2}$ and $\mathrm{SiO}_{2}$ are used for the self-cleaning. The $\mathrm{TiO}_{2}$ solution prepared was mixed with $\mathrm{SiO}_{2}$ and coated with the spin coating method. With only $\mathrm{TiO}_{2}$ applying, the reflection index of 2.71 was reduced to 1.37 by using $15 \% \mathrm{SiO}_{2}$ mixed [28]. In a study on the protective outer layer of the CdTe thin film solar cell, a multi-layer coating method was preferred. To reduce the loss due to the $4.2 \%$ reflection on the thin film glass, $\mathrm{ZrO}_{2}$ with high reflectance index was first applied and $\mathrm{SiO}_{2}$ with low reflectance index was applied above this $\mathrm{ZrO}_{2}$ layer. A four-layer coating was obtained. The deposition was carried out by evaporation after the layers were made. Reflection losses were reduced to $1.36 \%$ and an index of 1.44 was obtained. However, in this application, the flexibility of the properties of the thin films led to the deterioration of this coating. When the thin films were flexed, it was observed that the coating deteriorated [29]. In another study where the $\mathrm{SiO}_{2}$ coating was applied on BZO (Borondoped Zinc Oxide) thin film surface, the light transmittance of about $92 \%$ was increased to $95 \%$. Using the sol-gel dip coating method, a thickness of $90 \mathrm{~nm}$ could be obtained and this coating which is a reflectance index of 1.28 was found to be resistant to adverse weather conditions [19].

In another application, firstly, $\mathrm{ZrO}_{2}$ was applied to the glass on the thin film surface and then secondly $\mathrm{SiO}_{2}$, thirdly $\mathrm{ZrO}_{2}$ again, and $\mathrm{SiO}_{2}$ as the last layer. In this work, $\mathrm{ZrO}_{2}$ has high index and low index $\mathrm{SiO}_{2}$. In this way, a total thickness of $277 \mathrm{~nm}$ was obtained and the reflectance index decreased by $1.22 \%$ to 1.49 . In the same study, $335 \mathrm{~nm}$ thicknesses were obtained with sixlayer $\left(3 \mathrm{ZrO}_{2}+3 \mathrm{SiO}_{2}\right)$ AR coating obtained using the same method and the reflectance decreased by $1.49 \%$. The reflectance index of the six-layer application was 1.47 [30]. In 
the study on the CIGS (CuInGaSe $)$ thin film, the $\mathrm{SiO}_{2}$ and $\mathrm{WO}_{3}$ photocatalyst which has the self-cleaning Anti-reflective coating was applied. Due to the use of tungsten, the color of the surface coating is blackened and the reflectance index is measured as $1.3[20]$.

\section{CONCLUSION}

Because of the refraction and reflections from the surface when the sunrays meet the surface of the solar cell, there is a loss of efficiency even if the cell is positioned at the right angle. The solar cells meet with more solar rays and it is desired to increase the open circuit voltages and the energy intensities to obtain more power output. It is desired that to increase the open circuit voltages and the energy intensities to obtain more power output by meeting the solar cells with more solar rays.

Many methods and materials have been observed when investigating anti-reflection (AR) studies. In these studies, it was observed that the anti-reflective coatings (ARC) could be applied to the protective glass surface, to behind the glass and directly applied to the cell surface. The coating on the protective glass is very useful because they can be applied to existing PV energy systems and PV power plants without any change. It has also been shown that all of the work used in this method has been supplemented with self-cleaning materials and antireflection materials. With this combination, PV power plants will be able to achieve huge efficiency gains.

It has been observed that triple-layers of coatings are more durable and stable than the other multi-layers and also give results that are suitable for each type of solar cell. $\mathrm{SiO}_{2}, \mathrm{MgF}_{2}$ and $\mathrm{TiO}_{2}$ were used in the coatings. While $\mathrm{SiO}_{2}$ can be used as an anti-reflection coating alone, higher efficiency is obtained when it is supported by high reflection index materials such as $\mathrm{ZrO}_{2}$. $\mathrm{ZrO}_{2}$ was used as an alternative to $\mathrm{TiO}_{2}$. As an alternative to $\mathrm{TiO}_{2}, \mathrm{ZrO}_{2}, \mathrm{HfO}_{2}, \mathrm{Ta}_{2} \mathrm{O}_{5}$ and $\mathrm{Nb}_{2} \mathrm{O}_{5}$ are proposed.

It was observed with the difficulty of 4 or more layers of coatings and the adverse effect of increased thickness and the coatings were pulled away from the thin film surface during the test phase.

If an anti-reflective coating with self-cleaning properties is not used, anti-reflective coatings with a low reflectance index between the protective glass and the cell surface will provide solar cells with longer duration of use and efficiency.

\section{REFERENCES}

[1] C.D. Evans, D.T. Monteith, D.M Cooper, "Long-term increases in surface water dissolved organic carbon: observations, possible causes and environmental impacts", Environmental Pollution, vol. 137, pp. 55-71, 2005.

[2] B. Kumaragurubaran, S. Anandhi, "Reduction of reflection losses in solar cell using anti reflective coating", 2014 International conference on computation of power, energy, information and communication ICCPEIC, 2014.

[3] Fraunhofer Institue of Solar Energy Systems, 2015.

[4] Dimmler and Wachter, 2007.

[5] White paper for CIGS thin film solar cell technology, 2016.

[6] K. Branker, MJM Pathak, JM Pearce, "A review of solar photovoltaic levelized cost of electricity", Renew. Sustain. Energy, vol. 15, pp. 44704482, rev 2011.

[7] M. Eckhart, M. El-Ashry, D. Hales, K. Hamilton, P. Rae, "Renewables 2017 Global Status Report”, p. 33, 2017.

[8] D. Huh, J. Shin, M. Byun, S. Son, P. Jung, H. Choi, Y. Kim, H. Lee, "Analysis of long-term monitoring data of PV modüle with Siox-based anti-reflective patterned protective glass", Solar energy materials and solar cells, vol. 170, pp. 33-38, 2017.

[9] K.A Moharram, M.S, Abd-Elhady, Ha Kandil, H. el-Sherif, "Influence of cleaning using water and surfactants on the performance of photovoltaic panels", Energy Convers Manage, vol. 68, pp. 266-272, 2013.

[10] M.S. Abd- Elhady, M.M. Fouad, T. Khalil, Improving the efficiency of photovoltaic (PV) panels by oil coating, Energy conversion and management, vol. 115, pp. 1-7, 2016.

[11] A.T. Kearney Energy Transition Institute, IPCC 2011, Special Report on Renewable Energy, MIT 2015, The Future of Solar Energy

[12] L.A. Dobrzanski, M. Szindler, Sol gel $\mathrm{Tio}_{2}$ antireflection coating for silicon solar cells, Journal of achievements in materials and manufacturing engineering (JAMME), Vol. 52-1, 2012

[13] S. Yoon, G. Turner, V. Garboushian, Thin, lightweight, \%18 efficient space silicon solar cell and array, 25th PVSC, May 1996, Washington USA.

[14] X. Zhang, S. Cai, D. You, L. Yan, H. Lv, X. Yuan, B. Jiang, Templatefree sol-gel preparation of süperhydrophobic ORMOSIL films for doubleWavelength broadband antireflective coating, Adv. Funct. Mater., vol. 23, no. 25 , pp. 4361-4365, 2013.

[15] G. Rajan, K. Aryal, T. Ashrafee, S. Karki, S. Babcock, V. Ranjan, Realtime Optimization of Anti-reflective Coating for CIGS Solar Cells, Photovoltaic Specialists Conference (PVSC), 2016 IEEE 43rd, 22502253

[16] M.Z. Pakhuruddin, Y.Yusof, K.Ibrahim, A.A. Aziz, Fabrication and characterizaton of zinc oxide anti-reflective coating on flexible thin film microcrystalline silicon solar cell, Optik, vol. 124, pp. 5397-5400, 2013.

[17] F.Crisostomo, N.Hjerrild, S. Mesgari, Q. Li, R.A.Taylor, A hybrid PV/T collector using spectrally selective absorbing nanofluids, Applied Energy, vol. 193, pp. 1-14, 2017.

[18] U.G. Yasa, M.N. Erim, N. Erim, M.O. Girgin, H. Kurt, "Design of antireflective graded height nanogratings for photovoltaic applications", NUSOD 2017.

[19] N. Wang, J. Fang, X. Zhang, G. Wang, L. Wang, C. Liu, H. Zhao, Z. Chen, X.L. Chen, J. Sun, Y. Zhao, "Combined $\mathrm{SiO}_{2}$ antireflective coating with MOCVD-ZnO:B to improve light absorption in thin-film solar cells", Solar Energy Materials \& Solar Cells, vol. 130, pp. 420-425, 2014.

[20] Y. Ota, N. Ahmad, K. Nishioka, "A 3,2\% output increase in an existing photovoltaic system using an anti-reflection and anti-soiling silica-based coat", Solar Energy, vol.136, pp. 547-552, 2016.

[21] Y. Lu, X. Zhang, J. Huang, J. Li, T. Wei, P. Lan, Y. Yang, H. Xu, W. Song, "Investigation on antireflection coating for $\mathrm{Al}: \mathrm{ZnO}$ in silicon thinfilm solar cells", Optik, vol. 124, pp. 3392-3395, 2013.

[22] G. Rajan, T.Begou, K.Aryal, T.Ashrafee, S.Karki, V.Ranjan, A.A. Rockett, N.J. Podraza, R.W. Collins, S. Marsillac, "Optimization of multilayered anti-reflective coating for ultra-thin $\mathrm{Cu}(\mathrm{In}, \mathrm{Ga}) \mathrm{Se}_{2}$ Solar Cells", Photovoltaic Specialists Conference (PVSC), IEEE 43rd, pp. 1506-1510, 2016.

[23] D. Huh, J.H. Shin, M. Byun, S. Son, P.H. Jung, H.J. Choi, Y.D. Kim, H. Lee, "Analysis of long-term monitoring data of PV module with SiOxbased anti-reflective patterned protective glass", Solar Energy Materials and Solar Cells, vol.170, pp. 33-38, 2017.

[24] Y.Yuan, X.Lu, G.Yan, R.Hong, Sol-gel preparation of antireflective coating with abrasion resistance by base/acid double catalysis and surface treatment, Soalr Energy, 155, 2017, 1366-1372

[25] S. Yoon, G. Turner, V. Garboushian, Thin, lightweight, $18 \%$ efficient space silicon solar cell and array, 25th IEEE PV Conference, 1996, Washington DC USA, pp. 259-262.

[26] W. Abeygunasekara, V. Karunaratne, P. Hiralal, "Numerical Modelling of Zinc Oxide Nanowire Anti Reflective Coating", 10th IEEE International Conference on Industrial and Information Systems ICIIS, 2015, Sri Lanka, pp. 244-249.

[27] X. Huang, Y. Yuan, S. Liu, W. Wang, R. Hong, “One-step sol-gel preparation of hydrophobic antireflective $\mathrm{SiO}_{2}$ coating on poly(methyl methacrylate) substrate", Materials Letter, vol. 208, pp. 62-64, 2017.

[28] D.Adak, S.Ghosh, P.Chakrabarty, A.Mondal, H.Saha, R.Mukherjee, R.Bhattacharyya, Self-cleaning V-TiO2:SiO2 thin-film coating with enhanced transmission for solar glass cover and related applications, Solar Energy, vol. 155, pp. 410-418, 2017.

[29] G.Womack, P.M.Kaminski, J.M.Walls, "High Temperature Stability of Broadband Anti-reflection Coating on Soda Lime Glass for Solar Modules", Photovoltaic Specialist Conference (PVSC), 2015 IEEE 42nd, LA USA. 
[30] P.M. Kaminski, G. Womack, J.M. Walls, "Broadband Anti-reflection coating for thin film photovoltaics", Photovoltaic Specialist Conference (PVSC), 2014 IEEE 40th, Denver USA.

\section{BIOGRAPHIES}

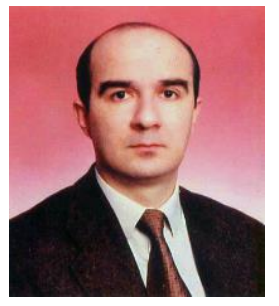

NAZMI EKREN received the B.S. degree from the Electrical Engineering Department, Yildiz Technical University (YTU), Istanbul, Turkey, in 1987, and the M.S. degrees from the Marmara University in 1989 and $\mathrm{PhD}$ degrees from the Istanbul University in 1996. He is currently an Assistant Professor at the Marmara University. His research interests PV systems, Nano technology and lighting. 